\section{THE PRICE OF FREEDOM*}

BY

\section{Sir FRANCIS WALSHE, M.D., F.R.C.P., F.R.S.}

I am honoured that you should invite me, who am not of your Fellowship, to address this annual meeting, though I am not sure that your officers fully realized what they were about when they made me free of this rostrum.

I have ventured to choose the words "the price of freedom" as the title of my remarks this afternoon, because, gazing upon the medical scene as a somewhat detached spectator who clung to his amateur status in 1948 , and who is neither follower nor followed, I have a strong impression that there are in our profession those who are not very interested in the notion of freedom, and that, of those who are interested, not all appreciate what must be done to keep it.

\section{Diversity of Outlooks}

Wise men have said that liberty can be preserved only by the united and the vigilant, but even in our most complacent moods we can hardly say of our profession that we are either vigilant or united in its regard. There are, of course, many excuses we may give ourselves for this state of affairs. Firstly, we may have different ideas of what constitutes freedom for our profession, and, secondly, we have diverse outlooks upon medicine itself.

The inevitable differentiation of roles which have been forced upon us by the increasingly complex nature of medicine has created many and varied ways of life for doctors. Some of these ways are extremely remote from the care of individual human persons, or even from contact with those healthy members of the community whose welfare by preventive medicine we seek to promote. On the other hand, many of us spend our working lives wholly or predominantly in contact with those who seek our aid.

Of all of us, the general practitioner is most deeply and continuously immersed in what I shall call the human situation, coping not merely with illness but with all the complications that may surround the lives, of the sick, raising issues far beyond the merely clinical. The specialist and consultant is, of course, less deeply involved here, while still less so is the doctor who works exclusively in hospitals. I always think of these last favoured individuals as the florists of medicine, who get their clinical flowers cut, neatly tied up, with the dead leaves cut off and the earwigs shaken off.

In contrast to them is the general practitioner, a real gardener who has to deal with the entire plant in its native soil, with all its weeds, parasites, domesticities, muck, and muddle, and with no one to do his fatigues for him. It is he who has over the generations built up the ideal of the doctor-patient relationship that we have inherited but that we now begin to see replaced in some quarters by a mere business relationship, under the influences of a National Health Service.

Such then being the varied circumstances of the doctor's life, it is not surprising that there should be amongst us different notions about professional freedom, and that the achievement of a general agreement amongst us of the optimal relation between the State and the doctor should be hard to come by.

\section{Thrice Defeated}

Surely, in an old, learned, and humane profession, with the most ancient code of professional ethics in the

\footnotetext{
*An address given to the Annual General Meeting of the Fellowship for Freedom in Medicine on November 23. A report of the meeting is published at page 187 in this week's Supplement.
}

world, there should be sufficient generality of understanding for us to be able to harmonize our sectional loyalties with our first loyalty to medicine as a whole. Yet, if we are to be realist, we must admit that nothing is plainer than that, in peacetime at least, we have proved unable to achieve a generally accepted synthesis of ideals. Thrice within my own professional life has our profession vigorously, even vociferously, stood out for a while against certain Government proposals designed to bring us within a narrower framework and one more subordinated to the State. Yet each time in the end we have fallen back, disunited, disgruntled, defeated, but acquiescent.

The present year has seen the latest of these unimpressive spectacles of instability and disunion: a negotiating committee with no real solidarity of aim among its disparate elements, each of these with different measures of freedom to negotiate, swearing that it would ne'er consent to a Royal Commission, and then, man by man, consenting, not having thought out before they began the consequences of a single one of their proposed actions, whether of advance or of retreat.

\section{Lessons of History}

Now I suppose none would dispute that some form of National Health Service is inevitable under modern conditions, but this is not to say that we can regard the present hastily imposed, over-centralized organization of lay civil servants that regulates the details of the doctor's life in ever increasing degree as reasonable in its structure, or as compatible with the greatest usefulness and the optimal development of British medicine as a constantly growing science.

I think that at this turning point in the history of our profession we should give some thought to its constitution. We are a corporation set up by statute-namely, by the Medical Acts of the last century. Under these Acts we have our own governing body, the General Medical Council, which exercises disciplinary powers over our professional lives, sets the standards of our training according to advances in knowledge, and sees to it that our educational institutions conform to those standards. This governing body within its range of authority gives equality to all doctors, and does not interfere with the details of our work.

There is another learned profession in a like situationnamely, the profession of the law. This also has its own government, though one not identical in form with our own. The Inns of Court. those ancient universities of the lawyers, and the Law Society exercise functions comparable with those of the General Medical Council.

There was a third learned profession-namely, the clergy of the Established Church-which in 1533, by a formal "Act of Submission," hąnded over to Henry VIII absolute control of its theological and ecclesiastical beliefs and activities, and the confusions of authority which this submission entailed are with us to-day. This should be a lesson to us to yield up none of our freedoms to the State.

I do not apologize for this incursion into history, for if we will not learn the lessons of history we are doomed.

\section{Permanent Official in Command}

Hitherto, the civil service as we have had it during the past century has never had detailed control over a learned profession. Its structure and its patterns of administration have been devised for quite other activities, and an administrative regime that might well, in its laborious fashion, be adequate for the Board of Trade, or the Ministry of Supply, or the Office of Works is on the face of it hardly likely to be appropriate to the organization of a profession the members of which, still in a majority of their number, enter into close human relationships with those whom they serve. We deal with men and women at their most helpless, their most anxious, their most emotional, even perhaps their most unreasonable. It is our tradition not only to provide them with the best that the science and art of medicine can provide, but also to treat them as human beings whose 
confidences we receive and whose individual interests are our first responsibility.

In brief, ours is both a learned and a humane profession, one which makes great demands upon judgment of human issues as well as upon strictly technical issues, which calls for the exercise of discretion and for qualities not only of sympathy but on occasion for firmness and control.

Who in his senses could have supposed that the reach-medown, or ready-made, pattern of ordinary civil service administration could contain, without strangling, such a situation? In 1948 there did not exist a single Minister or lay civil servant in any way qualified to set up a rational structure for a National Health Service, and the ensuing decade has done nothing to encourage us to believe that the civil servant has learned anything. He is not there to learn. but to force us into the Procrustean bed of his administration and to impose his will upon us. And what opportunities he has had! The troubled sequence of ephemeral Parliamentary figures that have held the office of Minister of Health has flitted too rapidly across the scene to have had any influence upon events. This Ministry is a sort. of Parliamentary Didcot Junction, where the hopeful aspirant to Cabinet rank waits in the chill breeze until the train arrives to carry him on to the city of his dreaming spires, his political Oxford.

In effect, the permanent official is in command, and for the first time in the history of his Service he has got his claws well into a learned profession and he will not willingly let go.

\section{In No Way Qualified}

Hitherto, then, the seat of order and government lay within our profession, in the hands of men who were themselves doctors and thus best placed to understand the nature of medicine and the conditions of its healthy life and growth and its adaptation to the needs of the community.

Our situation is now changed for the worse, and the head and centre of the organization of our activities has moved to Whitehall and fallen into the hands of a lay bureaucracy, to whom medicine is nothing more than a body of men and women, of activities and institutions there to be regulated according to a civil service pattern the details of which are not within our control.

It is Whitehall that now decides how doctors shall be graded, like fat stock, how many of this and that kind of hospital officer and registrar there shall be, to what specialties they shall be allotted, and where they may be allowed to go. In modern jargon, the Ministry sets all our "ceilings," and if-as must and does happen-its decisions are not always compatible with optimal medical needs, or even with common sense, then some person or persons have to bombard Whitehall by post, or go hat in hand to some permanent official to beg, persuade, or bully him to increase the allotment of this or that human or material item in the system, or to send it here or there-and all this with results that are wholly unpredictable and may bear no relation whatever to the medical needs of the situation.

Thus the centre of gravity of our profession has moved out of its proper orbit, and swings precariously, ineffectively, and-need I add-extravagantly, according to the decisions of a body of men in no way qualified to pronounce upon any question involving the applications of the art and science of medicine to the best interests of the community.

\section{Shadow Looms}

Now, I venture to say that if the State is to subsidize medical services this could have been done without the minute and detailed control of the doctors' activities and of hospital administration that we find. The universities are not supported in this crazy fashion, nor is that remarkable medical organızation the Medical Research Council, with its large medical and scientific staff and its many units, so infiltrated with fussy and futile interference. None of them could function if it were so.
Nor dare we hope that we have reached the limit of imprisonment within this fantastic administrative machine, for the shadow of a fully paid State medical service looms over us, with all that it implies of helotry for us and of the dehumanizing of medicine for our patients.

It is ominous tha! at this juncture a President of the Royal College of Physicians should have reminded us in April of last year in the columns of the British Medical Journal* that the policy of the College is one of firm and consistent co-operation with the Goverrment of the day. In this unqualified form the statement must give us ground for disquiet. Does it mean that if a Government introduced a Bill to impose a whole-time State-paid medical service the College would co-operate to this end, or would acquiesce in any other scheme a Government might propose in our regard? And if it does not mean this, what precisely does it mean? Is it no more than an historical note on past policy, with no reference to present or future, or is it the ill-omened offer of yet another "Act of Submission" by a learned profession to the State?

I have to confess that I was surprised that such a statement evoked no comment or protest from your Fellowship, for I know that no such submissive attitude informs it, that your Fellowship has as its prime interest the fullest freedom for medicine, and that it has drafted an alternative plan for a national medical service to avoid the ineptitudes of the Service we have.

\section{Overdue Task}

This last task, of course, I venture to think is one that the British Medical Association should have initiated nine years ago. There should have been set up and kept in being a standing study group to observe the workings of the Service in all its aspects. so that at the expiration of a decade it should have had a report ready embodying a comprehensive survey and a series of practical suggestions for reform where these seemed indicated.

I cannot help feeling that, if the Association had had the foresight and political sense the situation required, its negotiators would not have marched their heterogeneous army up the hill and down again last summer, with nothing in its brief but a request for pecuniary adjustments in a Service that the Association perfectly well knows needs far more than this done to it. Why give colour to the jibe that we are interested in nothing else than remuneration ?

The price of freedom is greater than we have shown any corporate signs of recognizing. It does not allow these recurrent manifestations of instability and disunion, this failure to provide ourselves with the exhaustive and ordered analysis of the working of the National Health Service that we must have if we are to put any brake upon the slow progress of events towards a full-time State-paid medical service or to make reasoned constructive suggestions.

I venture also to suggest that, if our purely academic corporations confined their intervention in respect of the improvement of the present Service to professional and scientific questions, their recommendations to the Government would benefit immensely in strength and prestige by the absence of claims or recommendations upon questions of remuneration. Let these be the task of other organizations best fitted to cope with them. In short, let us have some differentiation of function, for this is of the very essence of organization.

*Brain, W. R., Brit. med. J., 1956, 1, 857.

Men, Steel, and Technical Change (H.M.S.O., price 2s. net) is the first of a series of booklets sponsored by the Department of Scientific and Industrial Research on the results of research into problems connected with industrial progress. Among the problems discussed are those arising from automation and problems of management and human relations. The booklets will be either "industrial versions" of research reports or short reviews on research. 